\title{
KOJŲ RAUMENŲ STIPRINIMO IR TEMPIMO PRATIMŲ POVEIKIS MOTERŲ PLOKŠČIAPĖDYSTĖS POŽYMIAMS, PUSIAUSVYRAI BEI GYVENIMO KOKYBEI
}

\author{
Inesa Turauskaitè ${ }^{1}$, Laura Žlibinaite $\dot{\mathbf{Z}}^{\mathbf{1 , 2}}$ \\ ${ }^{1}$ Kauno kolegija, ${ }^{2}$ Lietuvos sporto universitetas
}

\section{SANTRAUKA}

Tyrimo pagrindimas. Nustatyta, kad sutrumpejjusių struktūrų tempimo bei nusilpusių raumenų stiprinimo pratimai gali sumažinti plokščiapėdystės požymius. Visgi neaišku, kaip kojų raumenų tempimo ir stiprinimo pratimai paveikia moterų plokščiapėdystès požymius, pusiausvyrą bei gyvenimo kokybę.

Tikslas - nustatyti kojų raumenų stiprinimo ir tempimo pratimų poveikị moterų plokščiapèdystès požymiams, pusiausvyrai bei gyvenimo kokybei.

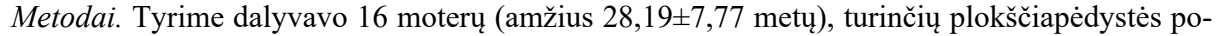
žymius. Tiriamosios atsitiktine tvarka buvo priskirtos ị vieną iš dviejų grupių: kojų raumenų stiprinimo arba tempimo pratimų grupę. Kineziterapija vyko nuotoliniu būdu keturias savaites, penkis kartus per savaitę, vieno užsièmimo trukmè - 30 min. Prieš ir po intervencijų buvo vertinama statinè ir dinaminè pusiausvyra, vidinis išilginis pèdos skliautas bei gyvenimo kokybė.

Rezultatai. Tiek po kojų raumenų stiprinimo, tiek po tempimo pratimų pakilo vidinis išilginis pèdos skliautas, pagerèjo pusiausvyros bei gyvenimo kokybès rodikliai $(p<0,05)$. Palyginus rezultatus tarp grupių, reikšmingo skirtumo nenustatyta nė vienam rodikliui.

Išvada. Kojų raumenų stiprinimo arba tempimo pratimai gali būti taikomi kaip veiksminga konservatyvi priemonė, kuri mažina moterų plokščiapedystės požymius, gerina pusiausvyrą ir gyvenimo kokybę.

Raktažodžiai: plokščiapėdystė, pratimai, pusiausvyra, pėdos skliautas, gyvenimo kokybė.

\section{IVADAS}

Žmogaus pėda yra sudètinga struktūra, kuri užtikrina stovėjimą ant dviejų kojų bei judejjimą. Tai vienintelè kūno dalis, kuri reguliariai liečiasi su atrama (Rithanya et al., 2018). Nors pėdos sudaro tik 5 proc. žmogaus kūno ploto, jos kontroliuoja laikyseną, užtikrina stabilumą išlaikant pusiausvyrą ir absorbuoja smūgius (Kim, Kim, 2016). Tyrimų duomenimis, 24 proc. vyresnių nei 45 metų asmenų, dažnai jaučia pėdų skausmą, iš jų maždaug du trečdaliai nurodo bent vidutinę negalią kasdieniame gyvenime, susijusią su jų pẻdų būkle (Menz et al., 2013). Netinkama avalynè, nutukimas, paveldètos ir lètinès ligos - tai veiksniai, kurie, laikui bėgant didina sutrikimų, susijusių su pėdų būkle, riziką (Abdel Fattah et al., 2006). Vienas iš tokių sutrikimų - plokščiapèdystė. 
Kojų raumenų stiprinimo ir tempimo pratimų poveikis moterų plokščiapėdystės požymiams, pusiausvyrai bei gyvenimo kokybei

İvairūs autoriai plokščiapèdystės paplitimą pateikia skirtingai - nuo 30 iki 60 proc., šis sutrikimas dažnèja (Pranckevičius et al., 2006; Kostkevičius ir Astromskas, 2010; Aenumulapalli et al., 2017). Dėl plokščiapėdystės žmogaus eisena tampa sunki, varginanti ir skausminga. Pėdos ir čiurnos skausmas neigiamai veikia su sveikata susijusią gyvenimo kokybę, nes sunkina kasdienių veiklų atlikimą, blogina pusiausvyrą (Menz et al., 2013).

Vienas iš konservatyviųjų plokščiapėdystės gydymo metodų yra kineziterapija (Lee et al., 2005; Gondo et al., 2016; Sativani, Pahlawi, 2020). Kineziterapijos procedūrų metu pagrindinis dèmesys turi būti sutelktas ị sutrumpejjusių struktūrų (šeivinių raumenų) ištempimą bei nusilpusių raumenų (giliųų pado raumenų, užpakalinio, priekinio blauzdos raumens, ilgojo nykščio lenkiamojo raumens) stiprinimą (Lenčiauskienè, 2020). Tačiau stinga duomenų apie kineziterapijos pratimų poveikị suaugusiujų plokščiapėdystei gydyti. Taigi, remdamiesi anksčiau atliktų tyrimų duomenimis, manome, kad po tempimo ir stiprinimo pratimų taikymo moterų, turinčių plokščiapėdystės požymių, vidinis išilginis pėdos skliautas pakils, o pusiausvyra bei gyvenimo kokybė pagerès.

Tyrimo tikslas - nustatyti kojų raumenų stiprinimo ir tempimo pratimų poveiki moterų plokščiapèdystės požymiams, pusiausvyrai bei gyvenimo kokybei.

\section{METODAI}

Tiriamieji. Tiriamujų imtis - savanorès darbingo amžiaus moterys. Tiriamujų atrankos kriterijai: 1) moteriškoji lytis; 2) amžius - 18-40 metų; 3) ChippauxSmirak indekso rezultatas $\geq 45$ proc.; 4 ) neserga degeneracinėmis sąnarių ligomis; 5) nepatyrusios kojų traumos arba operacijos.

Tyrime sutiko dalyvauti 16 moterų. Tiriamųu amžiaus vidurkis $-28,19 \pm 7,77$ metų. Tyrimo dalyvès atsitiktine tvarka buvo suskirstytos ị dvi grupes, kurios pagal amžiaus, ūgio, svorio, kūno masès indekso bei fizinio aktyvumo rodiklius buvo homogeniškos. Išsamesnè tiriamųjų charakteristika pateikiama 1 lentelèje.

\section{1 lentelè. Tiriamųjų charakteristika}

\begin{tabular}{|l|l|l|l|}
\hline \multicolumn{1}{|c|}{ Rodikliai } & $\begin{array}{c}\text { Stiprinimo pratimų } \\
\text { grupė }(\mathbf{n}=\mathbf{8})\end{array}$ & $\begin{array}{l}\text { Tempimo pratimų } \\
\text { grupe் }(\mathbf{n = 8})\end{array}$ & \multicolumn{1}{c|}{ p reikšmé } \\
\hline Amžius (metų) & $27,50 \pm 8,25$ & $28,88 \pm 7,75$ & 0,74 \\
\hline Ūgis $(\mathrm{cm})$ & $172,63 \pm 5,18$ & $170,00 \pm 9,17$ & 0,49 \\
\hline Svoris $(\mathrm{kg})$ & $66,38 \pm 9,33$ & $59,88 \pm 5,94$ & 0,12 \\
\hline KMI $\left(\mathrm{kg} / \mathrm{m}^{2}\right)$ & $22,29 \pm 3,20$ & $20,77 \pm 2,24$ & 0,29 \\
\hline $\begin{array}{l}\text { Fizinis aktyvumas per } \\
\text { savaitę (kartai) }\end{array}$ & $2,00 \pm 2,56$ & $1,38 \pm 1,06$ & 0,53 \\
\hline
\end{tabular}


Tyrimo organizavimas. Tyrimas atliktas $2021 \mathrm{~m}$. sausio-vasario mèn. Tyrimui atlikti gautas Kauno kolegijos Medicinos fakulteto Reabilitacijos katedros Bioetikos komiteto leidimas, remiantis protokolu Nr. Nr-1 (2020-12-13). Tiriamosios sutikimą dalyvauti patvirtino pasirašydamos Tiriamo asmens informavimo ir sutikimo formą, kurioje pateikta informacija apie tyrimą, jo tikslą bei anonimiškumo ir konfidencialumo principus.

Tyrimo dalyvès, atitikusios atrankos kriterijus, buvo tirtos du kartus - prieš ir po intervencijų. Tyrimo metu buvo vertinama tiriamujų statinè ir dinaminè pusiausvyra, vidinis išilginis pėdos skliautas bei gyvenimo kokybè. Pirmojo susitikimo metu tiriamujų buvo paprašyta užpildyti anketą raštu, siekiant išsiaiškinti jų amžių, svorị bei fizinį aktyvumą per pastarają savaitę.

Tiriamosioms buvo taikomos skirtingos kineziterapijos programos: vienai grupei - kojų raumenų stiprinimo pratimai, kitai grupei - kojų raumenų tempimo pratimai. Kineziterapija abiem grupėms vyko atskirai nuotoliniu būdu keturias savaites, penkis kartus per savaitę, vieno užsièmimo trukmé - 30 min.

Intervencijos. Kojų raumenų stiprinimo pratimų grupės dalyvėms didžiausias dèmesys buvo skiriamas nusilpusių raumenų (giliujų pado raumenų, užpakalinio blauzdos raumens, priekinio blauzdos raumens, ilgojo nykščio lenkiamojo raumens) stiprinimui. Buvo atliekama 18 ịvairių pratimų: skirtingų blauzdos ir pėdos judesių iš skirtingų padéčių: atsisėdus, atsigulus, naudojant pagalbines priemones (pvz., kamuoliukus, rankšluostį, vandens buteliuką). Tempimo pratimų grupès dalyvès atliko pratimus, skirtus sutrumpèjusių struktūrų (šeivinių raumenų, Achilo sausgyslès) ištempimui. Buvo atliekama 19 pratimų: blauzdos ir pédos raumenų statinis tempimas ịvairiomis kryptimis su padėties užlaikymu, iš skirtingų pradinių padèčių: sėdint, stovint, atsigulus.

\section{Tyrimo metodai}

Anketinè apklausa. Tiriamosios, pildydamos klausimyną, turejjo atsakyti ị keturis klausimus nurodydamos savo amžių, ūgị, svorị bei fizinị aktyvumą per savaitę.

Modifikuotas žvaigždès nuokrypio testas skirtas ịvertinti tiriamųų dinaminę pusiausvyrą. Šiame teste naudojamas prietaisas, sudarytas iš platformos ir nuo jos nusitęsiančios tiesès trimis kryptimis: priekine, šonine bei skersine. Nustumtam atstumui nustatyti naudojamas indikatorius, esantis ant kiekvienos tiesès. Testo metu tiriamoji basomis viena koja stovi ant platformos, o kitos kojos pirštais neliesdama žemès stumia indikatorių. Matuojamas atstumas nuo platformos centro iki indikatoriaus kraštinès.

Flamingo testas skirtas įvertinti tiriamujų statinę pusiausvyrą. Testas atliekamas atmerktomis akimis, be avalynès su parankesne koja. Šio testo metu tiriamosios tikslas - kuo ilgiau išstovèti ant buomelio pagal jo išilginę ašį. Kita, per kelią sulenkta koja viso testo metu laikoma tos pačios pusès ranka blauzdos distaliniame 
Kojų raumenų stiprinimo ir tempimo pratimų poveikis moterų plokščiapėdystės požymiams, pusiausvyrai bei gyvenimo kokybei

gale. Laisvą ranką testo atlikimo metu leidžiama atitraukti ị šalị ir taip padèti sau išlaikyti pusiausvyrą. Rezultatas - mėginimų išlaikyti pusiausvyrą, stovint viena koja ant buomelio, per 1 min. skaičius.

Chippaux-Smirak indeksas (CSI) vertina vidinị išilgini pėdos skliautą, kurio pokyčiai yra vienas iš pagrindinių plokščiapedystès požymių (Onodera et al., 2008). Tyrimui naudojama abiejų kojų pėdų atspaudai. Gautame atspaude viena linija brèžiama per siauriausią vidurinès pėdos dalies vietą, kita linija brěžiama per plačiausią priekinès pèdos dalies vietą (Shariff et al., 2017). Šios dvi tiesès turi būti lygiagrečios. Rezultato vertinimas: 0 proc. - aukštas skliautas, 0,1-29,9 proc. normali peda, 30-39,9 proc. - tarpinis skliautas, 40-44,9 proc. - žemas skliautas, 45 proc. arba daugiau - plokščiapèdyste (Riddiford-Harland et al., 2000).

Peržiūrèto pėdos funkcijos indekso trumpoji forma (angl. Foot function index revised short form [FFI-R SF]) skirta įvertinti pėdos ir čiurnos pažeidimų įtaką su kasdiene veikla susijusiai gyvenimo kokybei. Jis suskirstytas ị penkias subkategorijas: skausmas, sąstingis, sunkumai, veiklos ribojimas, socialinès problemos. Iš viso yra 34 klausimai. Kiekvienas atsakymas pateiktas 4 balų Likerto skalëje (kai 1 = skausmo nèra, 4 = stipriausias skausmas). Kuo mažiau surenkama balų, tuo geriau vertinama gyvenimo kokybè.

Statistinè duomenų analizė. Duomenų statistinè analizè atlikta naudojant „MS Excel“ ir „SPSS 17.0“ programų paketus. Visi rodmenys lentelèse, paveiksluose ir tekste pateikiami kaip vidurkiai \pm standartinis nuokrypis. Visi kintamieji buvo normaliai pasiskirstę pagal Kolmogorovo-Smirnovo testą. Dviejų nepriklausomų imčių kintamiesiems palyginti buvo naudotas nepriklausomų imčių Student'o (t) kriterijus, o priklausomų imčių kintamiesiems - priklausomų imčių Student'o (t) kriterijus. Duomenys statistiškai reikšmingi, kai $\mathrm{p}<0,05$.

\section{REZULTATAI}

Statinè pusiausvyra buvo vertinama atliekant Flamingo testą, rezultatai pateikiami 1 pav. Palyginus kojų raumenų stiprinimo pratimų grupės tiriamųjų statinės pusiausvyros vertinimo rezultatus prieš tyrimą ir po jo, nustatytas statistiškai reikšmingas pagerejimas $(\mathrm{p}<0,05)$. Palyginus kojų raumenų tempimo pratimų grupès tiriamụjų statinès pusiausvyros vertinimo rezultatus prieš tyrimą ir po jo, taip pat nustatytas statistiškai reikšmingas pagerejjimas $(\mathrm{p}<0,05)$. Palyginus statinès pusiausvyros vertinimo rezultatų pokytị tarp grupių reikšmingo skirtumo nenustatyta $(\mathrm{p}>0,05)$.

Dinaminè pusiausvyra buvo vertinama naudojant modifikuotą žvaigždės nuokrypio testą, rezultatai pateikiami 2 lentelèje. Vertinant modifikuoto žvaigždès nuokrypio testo rodiklius nustatytas statistiškai reikšmingas teigiamas abiejų gru- 
pių tiriamųjų abiejų kojų ir visomis kryptimis pokytis $(\mathrm{p}<0,05)$. Palyginus dinaminès pusiausvyros vertinimo rezultatų pokytị tarp grupių reikšmingo skirtumo nenustatyta $(\mathrm{p}>0,05)$.

Plokščiapeddystės požymiai buvo vertinti pagal vidinio išilginio pèdos skliauto vertinimo Chippaux-Smirak indeksą, rezultatai pateikiami 3 lentelejje. Prieš intervencijas visos tiriamosios turejjo dešinès pèdos plokščiapèdystę. Po stiprinimo pratimų taikymo: vienai tiriamajai (12,5 proc.) vidinis išilginis skliautas nepakito, trims (37,5 proc.) - pėdos skliautas pakito nuo plokščiapėdystės iki žemo skliauto, keturioms (50 proc.) - pakito iki tarpinio skliauto dešinejje pėdoje; vienai tiriamajai (12,5 proc.) vidinis išilginis pedos skliautas nepakito, dviem (25,0 proc.) pėdos skliautas pakito nuo plokščiapėdystès iki žemo skliauto, penkioms $(62,5$ proc.) - pakito iki tarpinio skliauto kairẻje pejdoje. Po tempimo pratimų taikymo vienai tiriamajai (12,5 proc.) vidinis išilginis skliautas nepakito, keturioms (50 proc.) - pėdos skliautas pakito nuo plokščiapèdystès iki žemo skliauto, trims $(37,5$ proc.) - pakito iki tarpinio skliauto dešinèje pėdoje; keturioms $(50,0$ proc. $)$ - pédos skliautas pakito nuo plokščiapedystès iki žemo skliauto, keturioms $(50,0$ proc.) pakito iki tarpinio skliauto kairèje pèdoje.

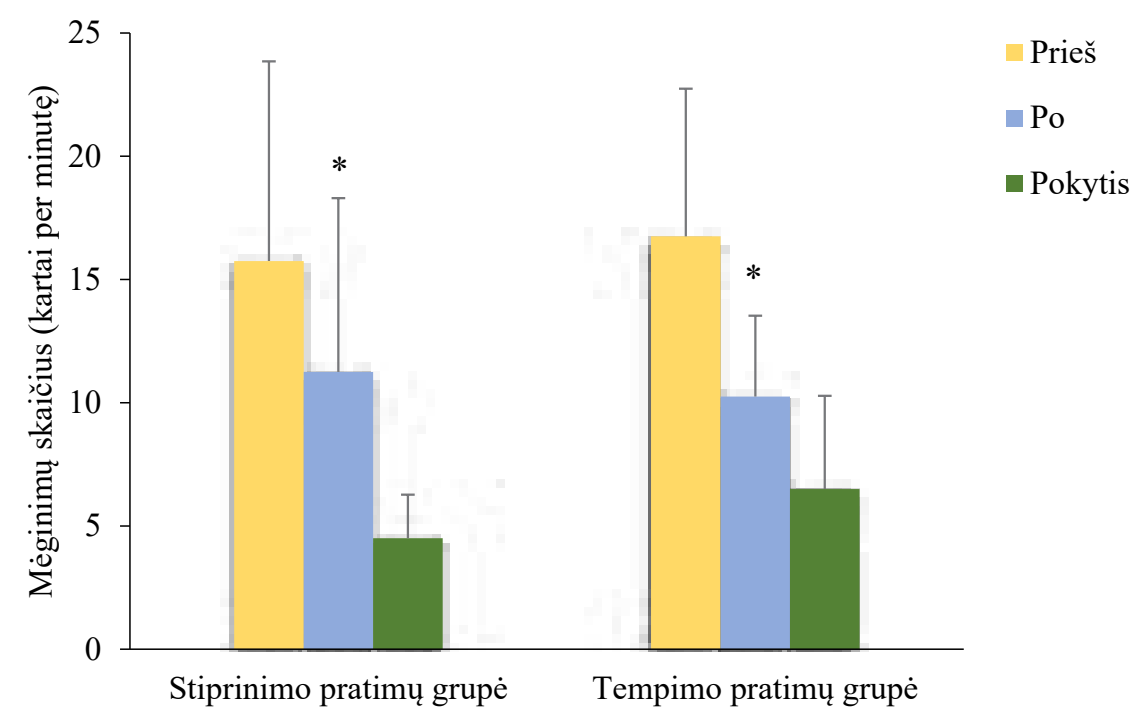

1 pav. Statinė pusiausvyra prieš intervencijas ir po jų $*_{-} \mathrm{p}<0,05$, palyginus su duomenimis prieš tyrimą. 
Kojų raumenų stiprinimo ir tempimo pratimų poveikis moterų plokščiapėdystės požymiams, pusiausvyrai bei gyvenimo kokybei

2 lentelè. Modifikuoto žvaigždès nuokrypio testo rodikliai

\begin{tabular}{|c|c|c|c|c|c|c|}
\hline \multirow{2}{*}{ Rodikliai } & \multicolumn{3}{|c|}{ Stiprinimo pratimų grupė } & \multicolumn{3}{|c|}{ Tempimo pratimų grupè } \\
\hline & Prieš & Po & $\mathbf{p}$ & Prieš & Po & $\mathbf{p}$ \\
\hline $\begin{array}{l}\text { Dešinès kojos } \\
\text { judesio ilgis i } \\
\text { prieki }(\mathrm{cm})\end{array}$ & $65,00 \pm 6,23$ & $69,00 \pm 5,71^{*}$ & $\mathrm{p}=0,001$ & $66,63 \pm 6,59$ & $71,88 \pm 4,16^{*}$ & $\mathrm{p}=0,002$ \\
\hline $\begin{array}{l}\text { Dešinės kojos } \\
\text { judesio ilgis i } \\
\text { šoną }(\mathrm{cm})\end{array}$ & $100,75 \pm 7,42$ & $104,63 \pm 8,21 *$ & $\mathrm{p}=0,001$ & $106,63 \pm 11,69$ & $111,38 \pm 8,68^{*}$ & $\mathrm{p}=0,006$ \\
\hline $\begin{array}{l}\text { Dešinès kojos } \\
\text { judesio ilgis ị } \\
\text { vidų }(\mathrm{cm})\end{array}$ & $98,75 \pm 8,35$ & $104,25 \pm 8,33^{*}$ & $\mathrm{p}=0,001$ & $102,00 \pm 10,52$ & $105,63 \pm 10,58^{*}$ & $\mathrm{p}=0,010$ \\
\hline $\begin{array}{l}\text { Kairès kojos } \\
\text { judesio ilgis i } \\
\text { prieki }(\mathrm{cm})\end{array}$ & $66,13 \pm 8,20$ & $69,63 \pm 7,99^{*}$ & $\mathrm{p}=0,002$ & $65,25 \pm 5,04$ & $70,63 \pm 5,76^{*}$ & $\mathrm{p}=0,001$ \\
\hline $\begin{array}{l}\text { Kairès kojos } \\
\text { judesio ilgis i } \\
\text { šoną }(\mathrm{cm})\end{array}$ & $100,75 \pm 12,89$ & $106,50 \pm 11,12 *$ & $p=0,007$ & $104,88 \pm 10,66$ & $109,50 \pm 8,04^{*}$ & $\mathrm{p}=0,036$ \\
\hline $\begin{array}{l}\text { Kairès kojos } \\
\text { judesio ilgis ị } \\
\text { vidų }(\mathrm{cm})\end{array}$ & $100,88 \pm 12,25$ & $105,38 \pm 0,25^{*}$ & $\mathrm{p}=0,014$ & $100,63 \pm 12,01$ & $107,00 \pm 9,43 *$ & $\mathrm{p}=0,005$ \\
\hline
\end{tabular}

$*_{-} \mathrm{p}<0,05$, palyginus su duomenimis prieš tyrimą

Po kojų raumenų stiprinimo pratimų taikymo pagerèjo tiriamųjų dešinès pèdos Chippaux-Smirak indekso rezultatai $(\mathrm{p}<0,05)$. Po kojų raumenų tempimo pratimų taikymo pagerèjo tiriamųų dešinès pėdos Chippaux-Smirak indekso rezultatai $(\mathrm{p}<0,05)$. Palyginus kojų raumenų stiprinimo pratimų grupės tiriamųų kairès pėdos Chippaux-Smirak indekso rezultatus prieš intervenciją ir po jos, nustatytas reikšmingas pagerèjimas $(\mathrm{p}<0,05)$. Palyginus kojų raumenų tempimo pratimų grupès tiriamujų kairès pėdos Chippaux-Smirak indekso rezultatus prieš intervenciją ir po jos, nustatytas statistiškai reikšmingas pagerèjimas $(\mathrm{p}<0,05)$. Palyginus Chippaux-Smirak indekso abiejų pėdų rezultatų pokytị tarp grupių statistiškai reikšmingo skirtumo nenustatyta $(\mathrm{p}>0,05)$.

Vertinant gyvenimo kokybę FFI-R SF klausimynu nustatytas reikšmingas teigiamas abiejų grupių rodiklių pagerèjimas po pratimų taikymo $(\mathrm{p}<0,05)$, tačiau skirtumo tarp grupių nenustatyta (2 pav.). 


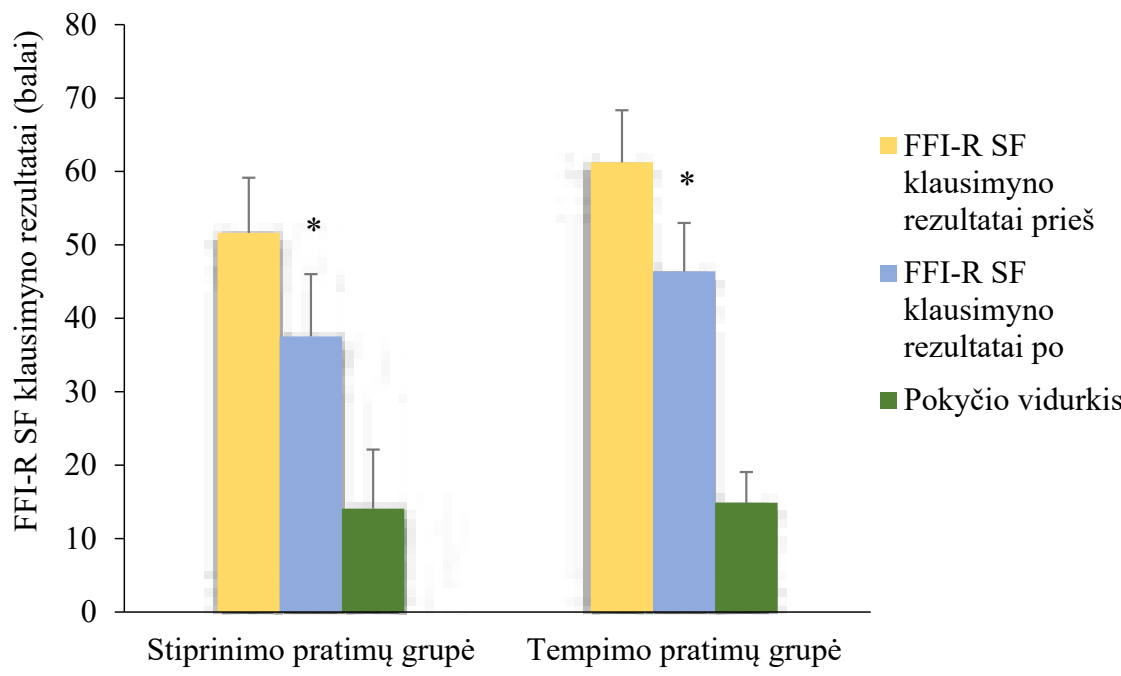

\section{2 pav. Gyvenimo kokybė prieš intervencijas ir po ju}

FFI-R SF klausimynas - peržiūrèto pėdos funkcijos indekso trumpoji forma,

* $-\mathrm{p}<0,05$, palyginus su duomenimis prieš tyrimą

3 lentelè. Pèdos vidinio išilginio skliauto vertinimo Chippaux-Smirak indeksas

\begin{tabular}{|c|c|c|c|c|c|c|}
\hline \multirow{2}{*}{ Rodikliai } & \multicolumn{3}{|c|}{ Stiprinimo pratimų grupė } & \multicolumn{3}{|c|}{ Tempimo pratimų grupė } \\
\hline & Prieš & Po & $\mathbf{p}$ & Prieš & Po & $\mathbf{p}$ \\
\hline $\begin{array}{l}\text { Chippaux- } \\
\text { Smirak } \\
\text { indeksas, } \\
\text { dešinė pėda, } \\
\text { proc. }\end{array}$ & $45,88 \pm 1,13$ & $40,38 \pm 2,26^{*}$ & $\mathrm{p}=0,000$ & $46,25 \pm 1,39$ & $40,50 \pm 3,67^{*}$ & $\mathrm{p}=0,001$ \\
\hline $\begin{array}{l}\text { Chippaux- } \\
\text { Smirak } \\
\text { indeksas, } \\
\text { kairè pėda, } \\
\text { proc. }\end{array}$ & $46,50 \pm 1,69$ & $40,25 \pm 2,32 *$ & $\mathrm{p}=0,000$ & $46,75 \pm 1,49$ & $40,50 \pm 2,78 *$ & $\mathrm{p}=0,001$ \\
\hline
\end{tabular}

$*-\mathrm{p}<0,05$, palyginus su duomenimis prieš tyrimą.

\section{REZULTATŲ APTARIMAS}

Tyrimo tikslas buvo nustatyti kojų raumenų stiprinimo ir tempimo pratimų poveikį moterų plokščiapėdystės požymiams, pusiausvyrai bei gyvenimo kokybei. Gauti duomenys rodo, kad tiek kojų raumenų stiprinimo, tiek kojų raumenų 
Kojų raumenų stiprinimo ir tempimo pratimų poveikis moterų plokščiapedystės požymiams, pusiausvyrai bei gyvenimo kokybei

tempimo pratimai veiksmingai pagerina moterų statinę bei dinaminę pusiausvyrą, pakelia vidinị išilginį pẻdos skliautą bei pagerina gyvenimo kokybę. Tarp grupių skirtumo nenustatyta, todèl negalime teigti, kad vienas metodas yra veiksmingesnis už kitą.

Mūsų tyrime nustatyta, kad, taikant kojų raumenų stiprinimo arba tempimo pratimus, pagerèjo moterų statinè bei dinaminè pusiausvyra. Tyrimo rezultatai sutampa su Lee et al. (2012) tyrimo duomenimis, tik jie tyrè jauno amžiaus moksleivius berniukus. Norint sumažinti plokščiapeddystès požymius bei pagerinti statinę pusiausvyrą, rekomenduojama korekcinių pratimų programa (Lee et al., 2012; Sativani \& Pahlawi, 2020; Pisal et al., 2020). Manoma, kad šis pagerejjimas gali būti aiškinamas tuo, jog atliekant vidinių pėdos raumenų stiprinimo pratimus, pagereja vidinio išilginio pėdos skliauto vientisumas ir jis pakyla, mažesnè apatinès pèdos dalis liečiasi su atrama, o daugiausia atramos tenka išoriniam pėdos skliautui (Lynn et al., 2012; Moon et al., 2014).

Mūsų tyrimo duomenimis, taikant kojų raumenų stiprinimo arba tempimo pratimus, pakyla moterų vidinis išilginis pedos skliautas, t. y. pakinta plokščiapėdystės požymiai. Rezultatai tik iš dalies sutampa su kitų autorių tyrimų duomenimis. 2019 m. buvo atliktas tyrimas, kurio metu vienai grupei buvo taikomi kojų dinaminio tempimo pratimai (15 mankštų), kitai grupei - kojų stiprinimo pratimai (15 mankštu). Šio tyrimo duomenimis, plokščiapeddystei gydyti dinaminio tempimo pratimai veiksmingesni nei raumenų stiprinimo pratimai (Gondo et al., 2019). Mūsų tyrimo rezultatai tarp skirtingų pratimų intervencijų nesiskyrè.

Plokščiapèdystė siejama su skirtingomis sveikatos būklèmis: moterys jaučia skausmą, nuovargi, prastesnè pédos funkcija (Yurt et al., 2018). Mūsų tyrimo duomenimis, prieš pratimų atlikimą tiriamujjų gyvenimo kokybẻ buvo reikšmingai blogesnè nei po jų. Minèti duomenys sutampa su kitų autorių duomenimis. Nustatyta, jog gyvenimo kokybė pagerèja, nes taikant fizinius pratimus sumažèja plokščiapėdystės laipsnis, tačiau kiti mokslininkai vertino vaikų, o ne suaugusiuju plokšCiapedystès laipsnị (Dokhov et al., 2019).

\section{IŠVADOS}

Galima teigti, jog tiek po kojų raumenų stiprinimo, tiek po tempimo pratimų, moterų plokščiapèdystès požymiai sumažejo, nes vidinis išilginis pẻdos skliautas pakilo, o statinè ir dinaminè pusiausvyra bei gyvenimo kokybė pagerejjo. Skirtumo, kuris metodas veiksmingesnis, nepavyko nustatyti.

Finansavimas: nėra.

Interesų atskleidimas: nèra. 


\section{LITERATŪRA}

Abdel Fattah, M. M., Hassanin, M. M., Felembane, F. A., \& Nassaane, M. T. (2006). Flat foot among Saudi Arabian army recruits: prevalence and risk factors. EMHJ-Eastern Mediterranean Health Journal, 12 (1-2), 211-217.

Aenumulapalli, A., Kulkarni, M. M., \& Gandotra, A. R. (2017). Prevalence of flexible flat foot in adults: A crosssectional study. Journal of clinical and diagnostic research: JCDR, 11 (6), AC17.

Dokhov, M. M., Sertakova, A. V., Rubashkin, S. A., \& Timaev, M. K. (2019). Quality of life in children with fat feet (planovalgus foot, longitudinal platypodia).

Gondo, A. A., Faadhilah, N., Nurjanati, D. A. et al. (2019). The Efficacy of Dynamic Stretching Exercise Versus Strengthening Exercise On Longitudinal Medial Arch in Flat Feet: Randomized Controlled Trial. Journal of Indonesian Physiotherapy, 1 (1), 1-6.

Gondo, A. A., Faadhilah, N., Nurjanati, D. A. et al. (2019). The Efficacy of Dynamic Stretching Exercise Versus Strengthening Exercise On Longitudinal Medial Arch in Flat Feet: Randomized Controlled Trial. Journal of Indonesian Physiotherapy, 1 (1), 1-6.

Yurt, Y., Şener, G., \& Yakut, Y. (2018). The effect of different foot orthoses on pain and health related quality of life in painful flexible flat foot: a randomized controlled trial. European journal of physical and rehabilitation medicine, 55 (1), 95-102.

Kim, E. K., \& Kim, J. S. (2016). The effects of short foot exercises and arch support insoles on improvement in the medial longitudinal arch and dynamic balance of flexible flatfoot patients. Journal of physical therapy science, 28 (11), 3136-3139. doi: 10.1589/jpts.28.3136

Kostkevičius, G., \& Astromskas, A. (2010). Visos bédos dèl pédos. Kaunas: Verslo respublika.

Lee, C. R., Kim, M. K., \& Cho, M. S. (2012). The relationship between balance and foot pressure in fatigue of the plantar intrinsic foot muscles of adults with flexible flatfoot. Journal of Physical Therapy Science, 24 (8), 699-701.

Lee, M. S., Vanore, J. V., Thomas, J. L. et al. (2005). Diagnosis and treatment of adult flatfoot. The Journal of Foot and Ankle Surgery, 44 (2), 78-113.

Lenčiauskienè, D. (2020). Kineziterapijos principai esant vaiku plokščiapédystei. Kaunas: Vitae Litera.

Lynn, S. K., Padilla, R. A., \& Tsang, K. K. (2012). Differences in static-and dynamic-balance task performance after 4 weeks of intrinsic-foot-muscle training: the short-foot exercise versus the towel-curl exercise. Journal of sport rehabilitation, 21 (4), 327-333.

Menz, H. B., Dufour, A. B., Riskowski, J. L. et al. (2013). Association of planus foot posture and pronated foot function with foot pain: the Framingham foot study. Arthritis care \& research, 65 (12), 1991-1999.

Moon, D. C., Kim, K., \& Lee, S. K. (2014). Immediate effect of short-foot exercise on dynamic balance of subjects with excessively pronated feet. Journal of physical therapy science, 26 (1), 117-119.

Onodera, A. N., Sacco, I. C. N., Morioka, E. H. et al. (2008). What is the best method for child longitudinal plantar arch assessment and when does arch maturation occur? The Foot, 18 (3), 142-149.

Pisal, S. N., Chotai, K., \& Patil, S. (2020). Effectiveness of Short Foot Exercises Versus Towel Curl Exercises to Improve Balance and Foot Posture in Individuals with Flexible Flat Foot. Indian Journal of Forensic Medicine \& Toxicology, 14 (3).

Pranckevičius, S., Koževnikovas, E., \& Petrulis, A. (2006). Viskas apie plokščiapédystę. Kaunas: Aesculapius.

Riddiford-Harland, D. L., Steele, J. R., \& Storlien, L. H. (2000). Does obesity influence foot structure in prepubescent children? International journal of obesity and related metabolic disorders, 24 (5), 541-544. doi: 10.1038/sj.ijo.0801192

Rithanya, P., Babu, K. Y., \& Mohanraj, K. G. (2018). Assessment of flat foot by plantar arch index using. Drug Invention Today, 10(11), 2142-2145.

Sativani, Z., \& Pahlawi, R. (2020). Foot Strengthening Exercise on Postural Balance and Functional Ability of Foot on Children 6-10 Years Old with Flexible Flatfoot. Jurnal Ilmiah Kesehatan, 2 (3), 99-107.

Shariff, S. M., Manaharan, T., Shariff, A. A., \& Merican, A. F. (2017). Evaluation of foot arch in adult women: Comparison between five different footprint parameters. Sains Malaysiana, 46 (10), 1839-1848. 
Kojų raumenų stiprinimo ir tempimo pratimų poveikis moterų plokščiapėdystės požymiams, pusiausvyrai bei gyvenimo kokybei

\title{
THE EFFECT OF LOWER LIMB MUSCLE STRENGTHENING AND STRETCHING EXERCISES ON FLATFOOT CONDITION, BALANCE AND QUALITY OF LIFE IN WOMEN
}

\author{
Inesa Turauskaitè1, Laura Žlibinaitè ${ }^{1,2}$ \\ ${ }^{1}$ Kaunas University of Applied Sciences, ${ }^{2}$ Lithuanian Sports University
}

Background. Studies show that stretching of shortened structures and strengthening of weakened muscles can reduce flat foot. However, it is not clear how lower extremity stretching and strengthening exercises affect balance and quality of life in women who have a flatfoot.

Aim. To determine the effect of lower limb strengthening and stretching exercises on the balance, foot arch and quality of life in women who have a flatfoot.

Methods. Sixteen women (28.19 \pm 7.77 years) with flatfoot participated in this study. Participants were randomly assigned to one of two groups: lower limb muscle strengthening or stretching exercises. The exercises were performed remotely for a total of four weeks, five times a week, for the duration of 30 minutes per session. Static and dynamic balance, medial longitudinal arch of the foot, and quality of life were assessed before and after the interventions.

Results. Static and dynamic balance, foot arch, and quality of life indicators improved in both exercise groups $(\mathrm{p}<0.05)$. No significant difference was found for any of the indicators when comparing the indicators between the two groups.

Conclusion. Lower limb muscle strengthening or stretching exercises can be used as an effective conservative treatment to reduce signs of flatfoot and improve balance and quality of life in women.

Keywords: flatfoot, exercise, balance, foot arch, quality of life.

Gautas 20210430

Priimtas 20210601 